\title{
Febrile neutropenia in chemotherapy treated small-cell lung cancer patients
}

\author{
Renata Rezonja Kukec ${ }^{1}$, Iztok Grabnar², Tomaz Vovk², Ales Mrhar², Viljem Kovac³, Tanja Cufer ${ }^{4}$ \\ ${ }^{1}$ Krka, d.d., Novo mesto, Slovenia \\ ${ }^{2}$ University of Ljubljana, Faculty of Pharmacy, Ljubljana, Slovenia \\ ${ }^{3}$ Institute of Oncology Ljubljana, Ljubljana, Slovenia \\ ${ }^{4}$ University Clinic Golnik, Golnik, Slovenia
}

Radiol Oncol 2015; 49(2): 173-180.

Received: 24 September 2014

Accepted: 15 October 2014

Correspondence to: Prof. Aleš Mrhar, Ph.D., Faculty of Pharmacy, University of Ljubljana, Aškerčeva 7, 1000 Ljubljana.

E-mail: ales.mrhar@ffa.uni-lj.si

Disclosure: No potential conflicts of interest were disclosed.

Background. Chemotherapy with platinum agent and etoposide for small-cell lung cancer (SCLC) is supposed to be associated with intermediate risk (10-20\%) of febrile neutropenia. Primary prophylaxis with granulocyte colonystimulating factors (G-CSFs) is not routinely recommended by the treatment guidelines. However, in clinical practice febrile neutropenia is often observed with standard etoposide/platinum regimen. The aim of this analysis was to evaluate the frequency of neutropenia and febrile neutropenia in advanced SCLC patients in the first cycle of standard chemotherapy. Furthermore, we explored the association between severe neutropenia and etoposide peak plasma levels in the same patients.

Methods. The case series based analysis of 17 patients with advanced SCLC treated with standard platinum/etoposide chemotherapy, already included in the pharmacokinetics study with etoposide, was performed. Grade 3/4 neutropenia and febrile neutropenia, observed after the first cycle are reported. The neutrophil counts were determined on day one of the second cycle unless symptoms potentially related to neutropenia occurred. Adverse events were classified according to Common Toxicity Criteria 4.0. Additionally, association between severe neutropenia and etoposide peak plasma concentrations, which were measured in the scope of pharmacokinetic study, was explored. Results. Two out of 17 patients received primary GCS-F prophylaxis. In 15 patient who did not receive primary prophylaxis the rates of both grade $3 / 4$ neutropenia and febrile neutropenia were high (8/15 (53.3\%) and 2/15 (13.3\%), respectively), already in the first cycle of chemotherapy. One patient died due to febrile neutropenia related pneumonia. Neutropenic events are assumed to be related to increased etoposide plasma concentrations after a standard etoposide and cisplatin dose. While the mean etoposide peak plasma concentration in the first cycle of chemotherapy was $17.6 \mathrm{mg} / \mathrm{l}$, the highest levels of 27.07 and $27.49 \mathrm{mg} / \mathrm{l}$ were determined in two patients with febrile neutropenia. Conclusions. Our study indicates that there is a need to reduce the risk of neutropenic events in chemotherapy treated advanced SCLC, starting in the first cycle. Mandatory use of primary G-CSF prophylaxis might be considered. Alternatively, use of improved risk models for identification of patients with increased risk for neutropenia and individualization of primary prophylaxis based on not only clinical characteristics but also on etoposide plasma concentration measurement, could be a new, promising options that deserves further evaluation.

Key words: small cell lung cancer; platinum-etoposide chemotherapy; etoposide; febrile neutropenia; plasma drug concentration

\section{Introduction}

Small cell lung cancer (SCLC) accounts for approximately $13 \%$ of all lung cancer diagnoses. It is very aggressive, growing rapidly and spreading early. Seventy percent of SCLC patients have extensive disease at the time of diagnosis. The standard therapeutic approach for extensive disease is chemo- 
TABLE 1. Factors associated with FN risk according to EORTC, ASCO, NCCN and ESMO guidelines

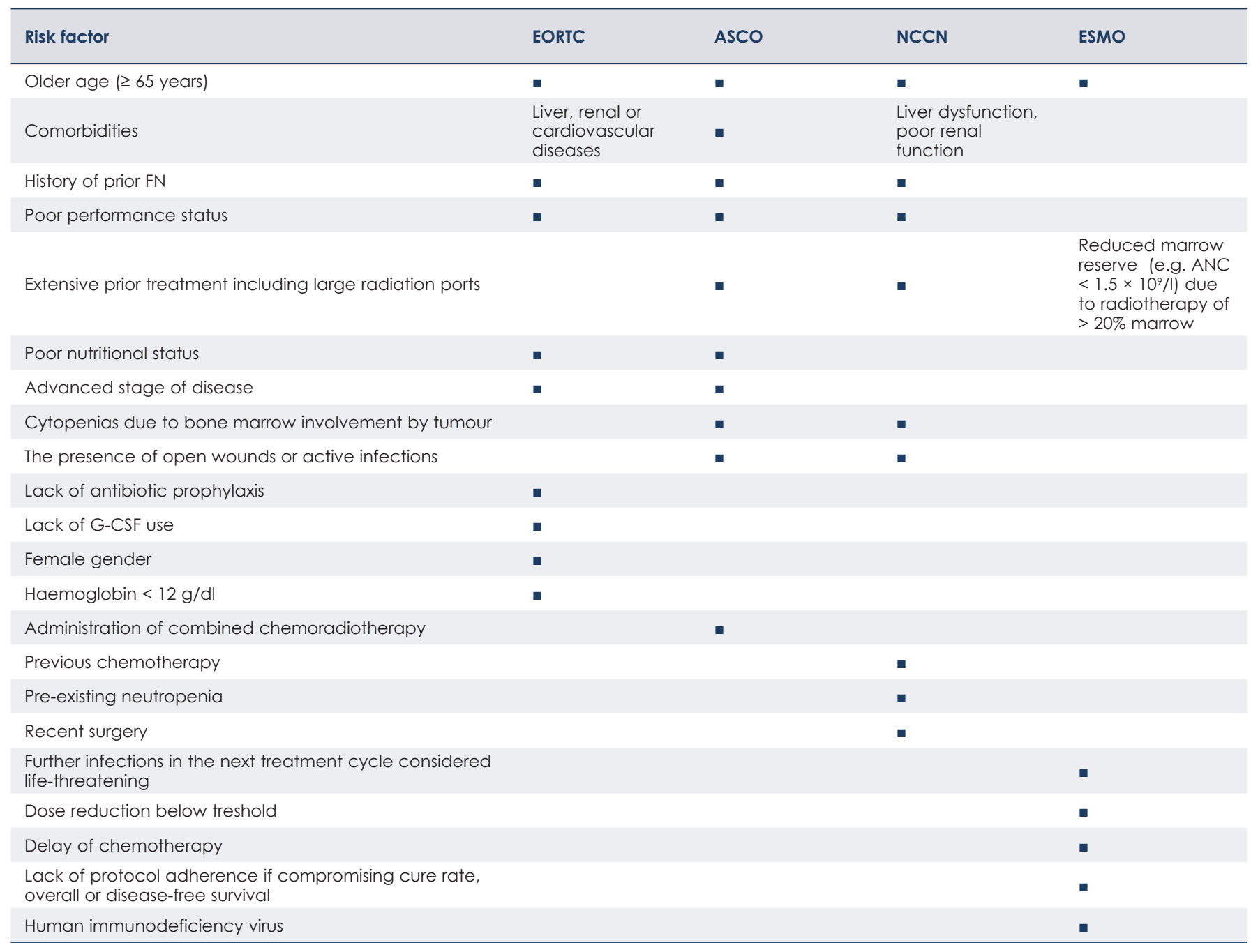

ANC = absolute neutrophil count; ASCO = American Society of Clinical Oncology; EORTC = European Organisation for Research and Treatment of Cancer; ESMO = European Society for Medical oncology; FN = febrile neutropenia; G-CSF = granulocyte colony-stimulating factor; NCCN = National Comprehensive Cancer Network

therapy with platinum agent and topoisomerase II inhibitor etoposide. ${ }^{1}$

Chemotherapy causes haematological as well as non-haematological adverse drug reactions. The most serious haematological toxicity is neutropenia, which can cause fatal septicaemia by suppressing the production of neutrophils and by cytotoxic effects on the cells that line the gastrointestinal tract allowing bacterial multiplication and invasion. ${ }^{2}$ Febrile neutropenia (FN) is a serious adverse event of chemotherapy characterized as an oral temperature $>38.5{ }^{\circ} \mathrm{C}$ or two consecutive readings of $>38$ ${ }^{\circ} \mathrm{C}$ for $2 \mathrm{~h}$ and an absolute neutrophil count (ANC) $<0.5 \times 10^{9} / 1$, or expected to fall below $0.5 \times 10^{9} / 1 .^{3} \mathrm{It}$ is associated with high morbidity, mortality, costs, and an increase of the risk for chemotherapy dose delays and/or reductions, or even discontinuation of chemotherapy.,5

Primary prophylaxis with granulocyte colonystimulating factors (G-CSFs), i.e. use with first cycle of chemotherapy, has been shown to significantly reduce the risk of FN; however, its use in all patients is not considered cost-effective., ${ }^{2,4}$ According to recommendations of the European Organisation for Research and Treatment of Cancer (EORTC) ${ }^{6}$, American Society of Clinical Oncology (ASCO) ${ }^{7}$, National Comprehensive Cancer Network $(\mathrm{NCCN})^{8}$, and European Society for Medical Oncology (ESMO) clinical practice guidelines", the prophylactic G-CSF is recommended when the risk of FN is high $(\geq 20 \%)$. Treatment-related risk factors classify chemotherapy regimens to high ( $\geq$ 
$20 \%)$, intermediate $(10-20 \%)$, or low risk $(<10 \%)$ for developing FN. ${ }^{4,6}$ When using a chemotherapy regimen associated with an intermediate (10-20\%) risk of FN other factors that may increase the overall risk of FN should be considered in making the decision to use prophylactic G-CSF. Guidelines indicate various risk factors, with an older age included in all four guidelines. Additional factors are history of prior FN, poor performance status (PS) and comorbidities ${ }^{7,8}$; for further details see Table 1. Recently, genetic factors which are not mentioned in the guidelines have also been associated with the risk of FN. ${ }^{4}$

According to EORTC and NCCN guidelines etoposide/platinum regimen for SCLC is associated with an intermediate risk of $\mathrm{FN}$, while in the ESMO guidelines which provide only the list of regimens with high risk of $\mathrm{FN}$, etoposide/platinum is not listed. ASCO guidelines do not indicate FN risk for any particular chemotherapeutic regimen. Based on the guidelines, primary prophylaxis with G-CSF in SCLC patients treated with etoposide/ platinum regimen is not recommended without a prior identification of a high risk of FN in each individual patient. However, in routine clinical practice FN seems to be frequent in advanced SCLC patients treated with standard etoposide/platinum regimen, who are not entitled to G-CSF prophylaxis.

To get additional information on febrile neutropenia in a first cycle of standard chemotherapy with etoposide/platinum, a post-planned analysis of the frequency of neutropenia and FN in a case series of patients with advanced SCLC, already included in a clinical trial of etoposide pharmacokinetics, was performed. Furthermore, analysis of association of severe neutropenia with previously measured levels of etoposide peak plasma concentration in the same patients during the first cycle of etoposide/cisplatin has been conducted.

\section{Patients and methods}

\section{Clinical observation}

The post-planned analysis of the frequency and grade of neutropenia and FN was conducted in a case series of patients in the first cycle of standard chemotherapy with etoposide/platinum. These patients were already included in a clinical trial of etoposide pharmacokinetics. Furthermore, association between severe neutropenia and etoposide peak plasma levels was explored.

Eligible patients were at least 18 years old receiving first-line chemotherapy with etoposide/plati- num for advanced SCLC confirmed by cytology or histology. Other entry criteria included World Health Organization PS 0-2, adequate haematological parameters and medical conditions allowing chemotherapy, satisfactory liver and renal function. The main exclusion criteria were Gilbert syndrome, Criegler-Najjar syndrome, active gastrointestinal disorders, and concomitant drugs entering the clinically important pharmacokinetic interactions. The Charlson comorbidity index was not assessed; however, patients with some comorbidities, such as liver or kidney dysfunction were excluded by the criteria of pharmacokinetic study. Patients gave written informed consent to participate in the pharmacokinetic study, which was approved by the Slovenian Ethics Committee for Research in Medicine (approval ref. no. 02/11/11) and was carried out according to the Helsinki Declaration.

Patients received a standard myelosuppressive chemotherapeutic regimen of etoposide and cisplatin or carboplatin without any concurrent irradiation. G-CSF prophylaxis was administered according to current guidelines. Planned dose of etoposide was of $100 \mathrm{mg} / \mathrm{m}^{2}$ intravenously on day 1 through 3. Cisplatin or carboplatin were administered intravenously on day 2 at a planned dose of $80 \mathrm{mg} / \mathrm{m}^{2}$ or at a target area under the curve (AUC) 5-6 $\mathrm{mg} \mathrm{min} / \mathrm{ml}$ (maximally $350 \mathrm{mg} / \mathrm{m}^{2}$ ), respectively. Patients were followed according to routine practice guidelines valid at that period at our university clinic. Neutrophil count was determined on day one of the next 3-week cycle, or earlier in case of clinical symptoms associated with neutropenia. If indicated, patients with severe neutropenia and/ or FN were hospitalized at our clinic. Grade 3/4 neutropenia and FN were classified according to Common Toxicity Criteria (NCI-CTC, version 4.0).

The reason for including only the first chemotherapy cycle in our post-planned analysis was relatively high rate of observed neutropenia grade $3 / 4$ or FN in the first cycle while using primary G-CSF prophylaxis according to current guidelines. The following cycles were not included into our analysis due to the fact that G-CSF prophylaxis had been used in the majority of patients in consecutive cycles. In addition, some patients in consecutive cycles received decreased etoposide dose or administration of chemotherapy was delayed.

\section{Pharmacokinetic sampling and drug assay} in the scope of pharmacokinetic study

Blood sampling was performed on days 1,2 and 3 in the first cycle of chemotherapy. Blood samples 
TABLE 2. Patients and treatment characteristics with the data on grade $3 / 4$ and febrile neutropenia in the first cycle

\begin{tabular}{|c|c|c|c|c|c|c|c|c|}
\hline $\begin{array}{l}\text { Patient } \\
n=17\end{array}$ & $\begin{array}{l}\text { Age } \\
\text { Mean } \\
\text { (range) }\end{array}$ & Sex & PS & $\begin{array}{l}\text { Etoposide } \\
\text { dose (\%) }\end{array}$ & $\begin{array}{l}\text { Neutropenia } \\
\text { grade }\end{array}$ & $\begin{array}{l}\text { FN } \\
\text { Yes/No }\end{array}$ & $\begin{array}{l}\text { G-CSF } \\
\text { prophylaxis }\end{array}$ & $\begin{array}{l}\text { Etoposide peak } \\
\text { plasma concentration } \\
\text { ( } 3 \text { days mean) }(\mathrm{mg} / \mathrm{l})\end{array}$ \\
\hline 1 & 60 & $\mathrm{~F}$ & 1 & 100 & 2 & No & No & 16.27 \\
\hline 2 & 62 & M & 0 & 100 & 4 & No & No & 14.43 \\
\hline 3 & 65 & M & 1 & 100 & 1 & No & No & 16.17 \\
\hline 4 & 60 & $M$ & 1 & 100 & 4 & $\begin{array}{l}\text { Yes, } \\
\text { death }\end{array}$ & No & 27.07 \\
\hline 5 & 64 & $\mathrm{~F}$ & 0 & 100 & 4 & Yes & No & 27.49 \\
\hline 6 & 78 & $M$ & 1 & 75 & 0 & No & No & 15.09 \\
\hline 7 & 51 & $M$ & 1 & 100 & 0 & No & Yes & 14.73 \\
\hline 8 & 73 & M & 1 & 100 & 1 & No & No & 17.04 \\
\hline 9 & 63 & $M$ & 1 & 100 & 1 & No & No & 17.88 \\
\hline 10 & 78 & M & 1 & 75 & 0 & No & No & 11.93 \\
\hline 11 & 62 & M & 1 & 75 & 0 & No & Yes & 10.59 \\
\hline 12 & 54 & M & 0 & 75 & 3 & No & No & 15.14 \\
\hline 13 & 63 & $\mathrm{~F}$ & 1 & 100 & 3 & No & No & 17.65 \\
\hline 14 & 64 & $M$ & 1 & 100 & 4 & No & No & 16.73 \\
\hline 15 & 65 & $F$ & 0 & 100 & 0 & No & No & 20.25 \\
\hline 16 & 66 & M & 0 & 100 & 4 & No & No & 23.71 \\
\hline 17 & 62 & M & 1 & 100 & 3 & No & No & 16.74 \\
\hline & $\begin{array}{l}64.1 \\
(51-78)\end{array}$ & & & & $\begin{array}{l}\text { Grade } 3 / 4: 8 / 17 \\
\text { (47.1\%) } \\
\text { Grade } 3 / 4 \\
\text { (no G-CSF): } 8 / 15 \\
\text { (53.3\%) } \\
\text { Grade } 1 / 2 \text { or } 0: \\
9 / 17(52.9 \%) \\
\text { Grade } 1 / 2 \text { or } 0 \\
\text { (no G-CSF): } 7 / 15 \\
\text { (46.7\%) }\end{array}$ & $\begin{array}{l}2 / 17 \\
(11.8 \%) \\
\text { No G-CSF } \\
2 / 15 \\
(13.3 \%)\end{array}$ & & $\begin{array}{l}17.6 \\
\text { (range 10.59-27.49) }\end{array}$ \\
\hline
\end{tabular}

FN = febrile neutropenia; $G-C S F=$ granulocyte colony-stimulating factor; $P S=$ performance status; $M=$ male; $F=$ female

$(6 \mathrm{ml})$ were collected at the end of etoposide 60 -min infusion. Samples were immediately placed on ice. Plasma was separated by centrifugation at $3000 \times$ $\mathrm{g}$ and $4{ }^{\circ} \mathrm{C}$ for $10 \mathrm{~min}$ and stored at $-80{ }^{\circ} \mathrm{C}$ until the analysis. Etoposide plasma concentration was determined by high-performance liquid chromatography with fluorimetric detection using a modified method of Krogh-Madsen et al. ${ }^{10}$ Linearity of the method was $0.125-30 \mathrm{mg} / 1$ with a lower limit of quantification of $0.125 \mathrm{mg} / \mathrm{l}$. The method was accurate (all deviations $\leq 10.3 \%$ ) and reproducible (coefficient of variability $\leq 7.22 \%$ intra-day and $\leq$ $7.33 \%$ inter-day).

\section{Results}

According to patients baseline characteristics presented in Table 2 our group of 17 patients repre- sents a typical population of advanced SCLC patients treated with chemotherapy, with a mean age of 64.1 years (range, 51-78 years), mostly males $(76.5 \%)$ and PS $\leq 2$. In the first cycle etoposide was administered in a full dose in 13 of all patients (76.5\%). Primary G-CSF prophylaxis was administered in only 2 patients $(11.8 \%)$.

Two out of 17 cases (11.8\%) of FN have been observed in the first cycle, one of these two patients died due to FN related pneumonia. Taken into account only 15 patients without primary prophylaxis with G-CSF the rate of $\mathrm{FN}$ was even higher, i.e. $13.3 \%(2 / 15)$. The whole rate of neutropenia grade $3 / 4$ after the first cycle was also quite high, it was recorded in 8 out of 15 patients not receiving primary G-CSF prophylaxis (53.3\%). Of note, in our study neutrophil count has only been determined on day one of the second cycle, unless symptoms potentially related to neutropenia occurred. 
TABLE 3. A summary of studies reporting risk of FN by ASCO, EORTC and NCCN guidelines

\begin{tabular}{|c|c|c|c|c|c|c|}
\hline Reference, year & $\begin{array}{l}\text { No of patients } \\
\text { entered }\end{array}$ & Treatment regimen & $\begin{array}{l}\% \text { pts with grade } \\
3 / 4 \text { neutropenia }\end{array}$ & $\begin{array}{l}\text { \% pts } \\
\text { with } \\
\text { FN }\end{array}$ & $\begin{array}{l}\text { Concurrent } \\
\text { radiotherapy }\end{array}$ & G-CSF \\
\hline $\begin{array}{l}\text { Roth et al. }{ }^{11} \\
1992\end{array}$ & 159 & $\begin{array}{l}\text { Etoposide } 80 \mathrm{mg} / \mathrm{m}^{2} / \mathrm{d} \text { i.v. for } 5 \text { days, } \\
\text { Cisplatin } 20 \mathrm{mg} / \mathrm{m}^{2} / \mathrm{d} \text { i.v. for } 5 \text { days, } \\
\text { every } 3 \text { weeks, } 4 \text { cycles }\end{array}$ & $\begin{array}{l}70 \\
\text { (granulocytopenia) }\end{array}$ & NR & $\begin{array}{l}\text { Yes (patients with } \\
\text { brain metastases). }\end{array}$ & No. \\
\hline $\begin{array}{l}\text { Skarlos et al. }{ }^{12}, \\
1994\end{array}$ & $\begin{array}{l}\text { Regimen A: } 73 \\
\text { Regimen B: } 74\end{array}$ & $\begin{array}{l}\text { Regimen A: } \\
\text { Etoposide } 100 \mathrm{mg} / \mathrm{m}^{2} / \mathrm{d} \text { i.v. days } 1-3 \text {, } \\
\text { Cisplatin } 50 \mathrm{mg} / \mathrm{m}^{2} / \mathrm{d} \text { day } 1 \text { to } 2 \\
\text { Regimen B: } \\
\text { Etoposide } 100 \mathrm{mg} / \mathrm{m}^{2} / \mathrm{d} \text { i.v. days } 1-3 \text {, } \\
\text { Carboplatin } 300 \mathrm{mg} / \mathrm{m}^{2} / \mathrm{d} \text { i.v. day } 1 \text {, } \\
\text { every } 3 \text { weeks, } 6 \mathrm{cycles}\end{array}$ & $N R$ & NR & $\begin{array}{l}\text { Yes (responding } \\
\text { limited disease } \\
\text { patients and } \\
\text { complete } \\
\text { responders with } \\
\text { extensive disease) }\end{array}$ & No. \\
\hline $\begin{array}{l}\text { Kosmidis et al. }{ }^{13}, \\
1994\end{array}$ & $\begin{array}{l}\text { Regimen A: } 73 \\
\text { Regimen B: } 74\end{array}$ & $\begin{array}{l}\text { Regimen A: } \\
\text { Etoposide } 100 \mathrm{mg} / \mathrm{m}^{2} / \mathrm{d} \text { i.v. days } 1-3 \text {, } \\
\text { Cisplatin } 50 \mathrm{mg} / \mathrm{m}^{2} / \mathrm{d} \text { day } 1 \text { to } 2 \\
\text { Regimen B: } \\
\text { Etoposide } 100 \mathrm{mg} / \mathrm{m}^{2} / \mathrm{d} \text { i.v. days } 1-3 \text {, } \\
\text { Carboplatin } 300 \mathrm{mg} / \mathrm{m}^{2} / \mathrm{d} \text { i.v. day } 1 \text {, } \\
\text { every } 3 \text { weeks, } 6 \mathrm{cycles}\end{array}$ & $N R$ & NR & $\begin{array}{l}\text { Yes (limited disease } \\
\text { patients) }\end{array}$ & No. \\
\hline
\end{tabular}

ASCO = American Society of Clinical Oncology; EORTC = European Organisation for Research and Treatment of Cancer; FN = febrile neutropenia; NCCN=National Comprehensive Cancer Network; G-CSF = granulocyte colony-stimulating factor; i.v. = intravenous administration; NR = not reported; pts = patients

In addition, mild grade $1 / 2$ neutropenia or normal neutrophil blood count have been observed in $7 / 15(46.7 \%)$ of patients without G-CSF prophylaxis on the scheduled day of the second cycle.

Mean etoposide peak plasma concentration in the first cycle of chemotherapy was $17.6 \mathrm{mg} / \mathrm{l}$ (from 10.59 to $27.49 \mathrm{mg} / \mathrm{l}$ ) (Table 2). Of note, the highest levels 27.07 and $27.49 \mathrm{mg} / \mathrm{l}$ were determined in two patients with FN. Patients with grade $3 / 4$ neutropenia not experiencing FN had also high mean peak plasma concentrations of $17.4 \mathrm{mg} / \mathrm{l}$ (from 14.43 to $23.71 \mathrm{mg} / \mathrm{l})$. Mean etoposide peak plasma concentration in patients with grade $1 / 2$ neutropenia was 16.84 (from 16.17 to $17.88 \mathrm{mg} / \mathrm{l}$ ), while patients who did not experience neutropenia had etoposide plasma level of $14.5 \mathrm{mg} / \mathrm{l}$ (from 10.59 to $20.25 \mathrm{mg} / \mathrm{l}$ ).

\section{Discussion}

According to the guidelines, G-CSF primary prophylaxis is mandatory when the overall risk of FN due to chemotherapy regimen and other factors is $\geq 20 \%$. Etoposide/platinum regimen for SCLC treatment is considered to be associated with $10-20 \%$ risk of FN and G-CSF primary prophylaxis is not unambiguously recommended by current guidelines. ${ }^{6-9} \mathrm{We}$ reviewed studies on the basis of which guidelines classified etoposide/platinum regimen for SCLC treatment into the intermediate risk group for $\mathrm{FN}$.

Taken together, according to EORTC, ASCO, NCCN and ESMO guidelines, information on FN rates in SCLC patients treated with etoposide/ platinum regimen is scarce. Only three published studies related to the risk of FN in SCLC patients treated by etoposide/cisplatin are cited ${ }^{11-13}$, two of them ${ }^{12,13}$ are even very likely the same study. Roth et al. ${ }^{11}$ reported grade $3 / 4$ granulocytopenia in $70 \%$ of patients, while in other two studies ${ }^{12,13}$ grade $3 / 4$ neutropenia was not even reported. FN was not reported in any of these studies. ${ }^{11-13}$ Of note, in all of these trials concomitant irradiation has been performed in selected patients (Table 3).

Therefore, we performed a comprehensive PubMed literature search to find additional data on grade $3 / 4$ neutropenia and FN rates in SCLC patients treated with first-line intravenous etoposide/ platinum regimen (etoposide dosage 240 to 420 $\mathrm{mg} / \mathrm{m}^{2}$ per cycle) without concurrent radiotherapy and G-CSF primary prophylaxis. In addition to the above 3 mentioned articles ${ }^{11-13}$, our literature search found nine studies ${ }^{14-22}$ (Table 4). In fact, our search confirmed a substantially high rate of grade $3 / 4$ neutropenia (51-91\%) observed in SCLC patients treated with etoposide/platinum chemotherapy given the fact that G-CSF use has been allowed in 3 out of nine trials. In addition, FN rates reported in five of these nine articles ${ }^{14-22}$ were in the range of $10-20 \%$ referred in the guidelines. ${ }^{6,8}$ The reported rates of FN during all, not only the first cycle of the chemotherapy, were in the range from $9.5 \%$ to $17 \%$, with the highest rate observed in the trial using relatively high daily dose of etoposide, i.e. 140 $\mathrm{mg} / \mathrm{m}^{2}$ for 3 days. ${ }^{16,18,19,21,22}$ Of note, data on neutropenia rates were based on all chemotherapy cycles and not just the first cycle.

In our limited series of patients, severe neutropenia G3/4 and FN were observed in unexpect- 
TABLE 4. A summary of comprehensive literature search of studies on FN and grade 3/4 neutropenia

\begin{tabular}{|c|c|c|c|c|c|}
\hline $\begin{array}{l}\text { Reference, } \\
\text { year }\end{array}$ & $\begin{array}{l}\text { No of patients } \\
\text { eligible for } \\
\text { evaluation }\end{array}$ & Treatment regimen & $\begin{array}{l}\text { G3/4 } \\
\text { neutropenia } \\
\text { (\% of pts) }\end{array}$ & $\begin{array}{l}\mathrm{FN} \\
\text { (\% of pts) }\end{array}$ & G-CSF prophylaxis \\
\hline $\begin{array}{l}\text { Miller et al. }{ }^{14} \text {, } \\
1995\end{array}$ & 156 & $\begin{array}{l}\text { Etoposide } 130 \mathrm{mg} / \mathrm{m}^{2} / \mathrm{d} \text { i.v. for } 3 \\
\text { days, cisplatin } 25 \mathrm{mg} / \mathrm{m}^{2} / \mathrm{d} \text { i.v. for } 3 \\
\text { days, every } 3 \text { weeks, up to } 8 \text { cycles }\end{array}$ & 85.0 & NR & No \\
\hline $\begin{array}{l}\text { Pujol et al. }{ }^{15} \text {, } \\
2001\end{array}$ & 109 & $\begin{array}{l}\text { Etoposide } 100 \mathrm{mg} / \mathrm{m}^{2} \text { i.v. days } 1-3 \\
\text { cisplatin } 100 \mathrm{mg} / \mathrm{m}^{2} \text { i.v. day } 1 \\
\text { every } 4 \text { weeks, up to } 6 \text { cycles }\end{array}$ & 91.0 & NR & No \\
\hline $\begin{array}{l}\text { Schiller et al. }{ }^{17} \text {, } \\
2001\end{array}$ & 402 & $\begin{array}{l}\text { Etoposide } 120 \mathrm{mg} / \mathrm{m}^{2} \text { i.v. days } 1-3 \text {, } \\
\text { cisplatin } 60 \mathrm{mg} / \mathrm{m}^{2} \text { i.v. day } 1 \\
\text { every } 3 \text { weeks, } 4 \text { cycles }\end{array}$ & 67.0 & $N R$ & $\begin{array}{l}\text { Used at the discretion of the } \\
\text { treating physician. (no data } \\
\text { on use) }\end{array}$ \\
\hline $\begin{array}{l}\text { Hanna et al. }{ }^{18} \text {, } \\
2006\end{array}$ & 106 & $\begin{array}{l}\text { Etoposide } 120 \mathrm{mg} / \mathrm{m}^{2} \text { i.v. days 1-3, } \\
\text { cisplatin } 60 \mathrm{mg} / \mathrm{m}^{2} \text { i.v. day } 1 \text {, } \\
\text { every } 3 \text { weeks, at least } 4 \text { cycles }\end{array}$ & 86.5 & 10.4 & $\begin{array}{l}\text { Used in accordance with } \\
\text { their package inserts or the } \\
1999 \text { guidelines from the } \\
\text { ASCO. (no data on use) }\end{array}$ \\
\hline $\begin{array}{l}\text { Lara et al. }{ }^{21} \text {, } \\
2009\end{array}$ & 324 & $\begin{array}{l}\text { Etoposide } 100 \mathrm{mg} / \mathrm{m}^{2} \text { i.v. days } 1-3 \text {, } \\
\text { cisplatin } 80 \mathrm{mg} / \mathrm{m}^{2} \text { i.v. day } 1 \\
\text { every } 3 \text { weeks, } 4 \text { cycles }\end{array}$ & 68.0 & 9.5 & $\begin{array}{l}\text { Use of G-CSF was allowed } \\
\text { per investigator discretion. } \\
\text { (no data on use) }\end{array}$ \\
\hline \multirow[t]{2}{*}{$\begin{array}{l}\text { Zatloukal et al.22, } \\
2010\end{array}$} & 203 & $\begin{array}{l}\text { Etoposide } 100 \mathrm{mg} / \mathrm{m}^{2} \text { i.v. days } 1-3 \text {, } \\
\text { cisplatin } 80 \mathrm{mg} / \mathrm{m}^{2} \text { i.v. day } 1 \text {, } \\
\text { every } 3 \text { weeks, } 6 \text { cycles }\end{array}$ & 59.6 & 9.9 & No \\
\hline & & & $\begin{array}{l}\text { Grade } 3 / 4 \\
\text { (range): } \\
51.0-91.0\end{array}$ & $\begin{array}{l}\text { FN (range): } \\
9.5-17.0\end{array}$ & \\
\hline
\end{tabular}

ASCO=American Society of Clinical Oncology; $d=$ day; FN = febrile neutropenia; G-CSF = granulocyte colony-stimulating factor; i.v. = intravenous administration; NR = not reported; pts = patients;

edly high portion of patients not receiving primary G-CSF prophylaxis already in the first cycle of platinum/etoposide chemotherapy; neutropenia $G$ $3 / 4$ developed in more than half patients $(53.3 \%)$ and FN developed in 2 out of 15 patients. Of note, neutropenia and FN were recorded after the first cycle of the chemotherapy based on the neutrophil count determined only on day one of the second cycle, unless symptoms potentially related to neutropenia occurred. In addition, only 12 out of these 15 patients without G-CSF prophylaxis received the full dose of etoposide. Patient 4 was on long-term treatment with corticosteroids. This patient developed FN with lung infection and died. Taken together, more than half of our patients not receiving primary G-CSF prophylaxis developed at least grade $3 / 4$ neutropenia already in the first cycle, with FN representing a quarter of these eight patients. None of the patients on primary G-CSF prophylaxis developed grade $3 / 4$ neutropenia. Based on this observation most of our consecutive patients included into the prospective etoposide pharmacokinetic study received primary GCS-F prophylaxis and are not included in this analysis.

Compared to the literature search data showing the rate of grade 3/4 neutropenia between 51 and $91 \%$ and $\mathrm{FN}$ rate between 9.5 and $17 \%$ after all cycles in the population of patients not receiving primary prophylaxis with G-CSF the $53.3 \%$ rate of grade $3 / 4$ neutropenia and $13.3 \%$ rate of $\mathrm{FN}$ observed in our patients already in the first cycle without G-CSF prophylaxis is rather high. Taking into account 4 additional patients with grade $1 / 2$ neutropenia recorded on the day one of the second cycle (including one patient taking corticosteroids chronically), the number of grade 3/4 neutropenia in the first cycle might be even higher, if the ANC was measured in the middle of the first chemotherapy cycle.

Despite the fact that the majority of our patients did not classify to high risk FN due to first-line chemotherapy, no concurrent palliative irradiation, good PS, no major comorbidities and normal kidney, liver and bone marrow function, which were all prerequisites for patients to be included into 
the pharmacokinetic trial, the rate of $\mathrm{FN}$ and 3/4 neutropenia observed after first cycle of the chemotherapy was substantially high. The reason for this might be in the fact that half of our patients were older than 65 years and all of them had advanced disease. Age more than 65 years has not been taken as high-risk criteria per se in our selected population of patients without comorbidities and with a good PS included into the pharmacokinetic trial. Obviously in elderly, fragile population the use of comprehensive geriatric assessment might improve our efforts to better identify patients with an increased risk of cytotoxic drugs complications. ${ }^{23}$ However, so far there are no reported prognostic validation studies using comprehensive geriatric assessment for decision on prophylactic use of G-CSF. In addition, we have still not found a score that would help us select these patients in a more comprehensive fashion.

EORTC, ASCO, NCCN and ESMO guidelines indicate various risk factors that predispose to increased risk of FN. Older age is the only factor included in all four guidelines. EORTC guidelines define older age even as patient-related risk factor most consistently associated with an increased FN risk. ${ }^{6}$ However, Crawford et al. tested various patient's baseline characteristics as possible risk factors for $\geq 1$ event of FN, including age, body weight, body surface area, sex, PS, disease stage, and neoplastic disease involvement in the marrow. Surprisingly, only sex was marginally predictive in their study, while patient age was not found to be a risk factor for $\mathrm{FN} .{ }^{24}$

The association between neutropenic events and etoposide peak plasma concentration has been well perceived by our analysis. According to the literature etoposide therapeutic trough serum concentration range in cancer patients is 2 to $6 \mathrm{mg} / \mathrm{l}$ and peak, 8 to $14 \mathrm{mg} / 1 .{ }^{25} \mathrm{In}$ all our groups of patients, i.e. patients with $\mathrm{FN}$, grade $3 / 4$ neutropenia, grade $1 / 2$ neutropenia and without neutropenia, mean peak plasma concentration of etoposide was above therapeutic level (i.e. $14 \mathrm{mg} / \mathrm{l})$. However, relatedness of mean peak plasma concentration height with severity of neutropenia was observed; concentrations were the highest in patients with FN and declined to the lowest levels observed in patients without neutropenia. Based on the fact that the mean etoposide peak plasma concentration was above therapeutic level also in patients without neutropenia could be anticipated that the frequency of (highgrade) neutropenia would be even higher if neutrophils were measured at the time of the largest expected neutrophil nadir.
On another point, peak plasma etoposide concentrations in two patients (one of them did not receive G-CSF prophylaxis) not experiencing neutropenia were within therapeutic range. Interestingly enough, in patient 7 etoposide plasma concentration was increased $(14.73 \mathrm{mg} / \mathrm{l})$ after dosage of etoposide; however, primary G-CSF prophylaxis was received and neutropenia did not develop. These data raised the question of whether high plasma concentrations measured immediately after the first application of etoposide on day one of the three day application course could help in selection of patients for primary G-CSF prophylaxis.

Our analysis is limited by the biases of selected patient population with good PS, without major comorbidities, treated in a controlled situation in the frame of the prospective clinical study. Additionally, the number of the patients is low and neutrophil counts were routinely measured only on the day one of the second cycle and not at the time of the largest expected neutrophil nadir in the middle of the cycle. But, all these limitations do not compromise our conclusion that the risk of FN in advanced SCLC population of patients treated with etoposide/platinum is substantially high. In a real world scenario the probability of $\mathrm{FN}$ in these patients might be even higher.

The goal is to develop a comprehensive risk models for FN which can be used as a guide whether or not to incorporate primary G-CSF prophylaxis for each individual patient. ${ }^{26,27}$ Some predictive models for neutropenia in the first cycle have already been proposed. However, a prospective study is needed for their validation. On the other hand, individualization of etoposide dosage taking into account pharmacokinetic parameters as well as genetic factors such as genetic polymorphisms, which can also affect drug plasma concentrations, is another option that has to be considered..$^{28}$

\section{Conclusions}

According to the guidelines etoposide/platinum regimen for SCLC treatment is not associated with high $\geq 20 \%$ risk of FN and primary G-CSF prophylaxis is therefore not mandatory. However, in our case series analysis of selected advanced SCLC patients included in a prospective pharmacokinetic trial, the rate of neutropenic complications in patients not receiving primary G-CSF prophylaxis was substantially high, already in the first cycle. Advanced SCLC patients treated with a standard dose of etoposide in combination with platinum 
may have increased plasma etoposide concentrations as reported in our patients and may therefore be at increased risk for high grade neutropenia and FN.

There is a need of greater effort to reduce the risk of neutropenic events starting in the first cycle. To avoid overuse of G-CSF a better prediction of post-chemotherapy neutropenic events, based on etoposide peak plasma concentration, might be of great value. An option could be the development and validation of risk models for severe neutropenia, based on etoposide plasma concentration on day one of the first cycle, a strategy that deserves further evaluation.

\section{References}

1. Califano R, Abidin AZ, Peck R, Faivre-Finn C, Lorigan P. Management of Small Cell Lung Cancer. Recent developments for optimal care. Drugs 2012; 72 471-90.

2. Crawford J, Dale DC, Lyman GH. Chemotherapy-induced neutropenia. Risks, consequences, and new directions for its management. Cancer 2004; 100 228-37.

3. de Naurois J, Novitzky-Basso I, Gill MJ, Marti Marti F, Cullen MH, Roila F, et al. Management of febrile neutropenia: ESMO clinical practice guidelines. Ann Oncol 2010; 21(Suppl 5): v252-6.

4. Lyman GH, Abella E, Pettengell R. Risk factors for febrile neutropenia among patients with cancer receiving chemotherapy: a systematic review. Crit Rev Oncol Hematol 2014; 90: 190-9.

5. Cooper KL, Madan J, Whyte S, Stevenson MD, Akehurst RL. Granulocyte colony-stimulating factors for febrile neutropenia prophylaxis following chemotherapy: systematic review and meta-analysis. BMC Cancer 2011; 11: 1471-2407.

6. Aapro MS, Bohlius J, Cameron DA, Dal Lago L, Donnely JP, Kearney N, et al. 2010 update of EORTC guidelines for the use of granulocyte-colony stimulating factor to reduce the incidence of chemotherapy-induced febrile neutropenia in adult patients with lymphoproliferative disorders and solid tumors. Eur J Cancer 2011; 47: 8-32.

7. Smith TJ, Khatcheressian J, Lyman GH, Ozer H, Armitage JO, Balducci L, et al. 2006 Update of recommendations for the use of white blood cell growth factors: An evidence-based clinical practice guideline. J Clin Oncol 2006; 24 3187-205.

8. National Comprehensive Cancer Network. NCCN Guidelines Version 2.2013. Available from: http://www.nccn.org/professionals/physician_gls/f_guidelines.asp\#myeloid growthMyeloid growth factors. Accessed 11 September 2013.

9. Crawford J, Caserta C, Roila F. Haematopoietic growth factors: ESMO clinical practice guidelines for the applications. Ann Oncol 2010; 21(Suppl 5): v24851.

10. Krogh-Madsen $M$, Honoré Hansen S, Hartvig Honoré P. Simultaneous determination of cytosine arabinoside, daunorubicin and etoposide in human plasma. J Chromatogr B 2010; 878: 1967-72.

11. Roth BJ, Johnson DH, Einhorn LH, Schacter LP, Cherng NC, Cohen $\mathrm{HJ}$, et al. Randomized study of cyclophosphamide, doxorubicin, and vincristine versus etoposide and cisplatin versus alternation of these two regimens in extensive small-cell lung cancer: a phase III trial of the Southeastern Cancer Study Group. J Clin Oncol 1992; 10: 282-91.

12. Skarlos DV, Samantas E, Kosmidis P, Fountzilas G, Angelidou M, Palamida $\mathrm{Ph}$, et al. Randomized comparison of etoposide-cisplatin vs. etoposidecarboplatin and irradiation in small-cell lung cancer. A Hellenic Co-operative Oncology Group Study. Ann Oncol 1994; 5: 601-7.
13. Kosmidis PA, Samantas E, Fountzilas G, Pavlidis N, Apostolopoulou F, Skarlos D. Cisplatin/etoposide versus carboplatin/ etoposide chemotherapy and irradiation in small cell lung cancer randomized phase II study. Hellenic Cooperative Oncology Group for Lung Cancer Trials. Semin Oncol 1994; 21(Suppl 6): 23-30.

14. Miller AA, Herndon JE 2nd, Hollis DR, Ellerton J, Langleben A, Richards F 2nd et al. Schedule dependency of 21-day oral versus 3-day intravenous etoposide in combination with intravenous cisplatin in extensive-stage small-cell lung cancer: a randomized phase III study of the Cancer and Leukemia Group B. J Clin Oncol 1995; 13: 1871-9.

15. Pujol JL, Daurès JP, Rivière A, Quoix E, Westeel V, Quantin X, et al. Etoposide plus cisplatin with or without the combination of 4 '-epidoxorubicin plus cyclophosphamide in treatment of extensive small-cell lung cancer: a French Federation of Cancer Institutes multicenter phase III randomized study. $J$ Natl Cancer Inst 2001; 93: 300-8.

16. Quoix E, Breton JL, Daniel C, Jacoulet P, Debieuvre D, Paillot N, et al. Etoposide phosphate with carboplatin in the treatment of elderly patients with small-cell lung cancer: a phase II study. Ann Oncol 2001; 12: 957-62.

17. Schiller JH, Adak S, Cella D, DeVore RF $3^{\text {rd }}$, Johnson DH. Topotecan versus observation after cisplatin plus etoposide in extensive-stage small-cell lung cancer: E7593-a phase III trial of the Eastern Cooperative Oncology Group. J Clin Oncol 2001; 19: 2114-22.

18. Hanna N, Bunn Jr. PA, Langer C, Einhorn L, Guthrie T Jr, Beck T, et al. Randomized phase III trial comparing irinotekan/cisplatin with etoposide/ cisplatin in patients with previously untreated extensive stage disease smallcell lung cancer. J Clin Oncol 2006; 24: 2038-43.

19. Schmittel A, Fischer von Weikersthal L, Sebastian M, Martus P, Schulze K, Hortig P, et al. A randomized phase II trial of irinotekan plus carboplatin versus etoposide plus carboplatin treatment in patients with extended disease small-cell lung cancer. Ann Oncol 2006; 17: 663-7.

20. Heigener DF, Manegold C, Jäger E, Saal JG, Zuna I, Gatzemeier U. Multicenter randomized open-label phase III study comparing efficacy, safety, and tolerability of conventional carboplatin plus etoposide versus dose-intensified carboplatin plus etoposide plus lenograstim in small-cell lung cancer in "extensive disease" stage. Am J Clin Oncol 2009; 32: 61-4.

21. Lara PN Jr, Natale R, Crowley J, Lenz HJ, Redman MW, Carleton JE, et al. Phase III trial of irinotecan/cisplatin compared with etoposide/cisplatin in extensive-stage small-cell lung cancer: clinical and pharmacogenomic results from SWOG S0124. J Clin Oncol 2009; 27: 2530-5.

22. Zatloukal P, Cardenal F, Szczesna A, Gorbunova V, Moiseyenko V, Zhang X et al. A multicenter international randomized phase III study comparing cisplatin in combination with irinotecan or etoposide in previously untreated small-cell lung cancer patients with extensive disease. Ann Oncol 2010; 21 : 1810-6.

23. Maas HAAM, Janssen-Heijnen MLG, Olde Rikkert MGM, Machteld Wymenga AN. Comprehensive Geriatric assessment and its clinical impact in oncology. Eur J Cancer 2007; 43: 2161-9.

24. Crawford J, Glaspy JA, Stoller RG, Tomita DK, Vincent ME, McGuire BW, et al. Final results of a placebo-controlled study of filgrastim in small-cell lung cancer: exploration of risk factors for febrile neutropenia. Support Cancer Ther 2005; 3: 36-46.

25. Clarke's analysis of drugs and poisons. Moffat AC, Osselton MD, Widdop B, Watts J, editors. Available from: http://www.medicinescomplete.com $/ \mathrm{mc} /$ clarke/current/CLK0691.htm?q=etoposide\&t=search\&ss=text\&p=1\# hit. Accessed 19 September 2013.

26. López-Pousa A, Rifà J, Casas de Tejerina A, González-Larriba JL, Iglesias C, Gasquet JA, et al. Risk assessment model for first-cycle chemotherapyinduced neutropenia in patients with solid tumors. Eur J Cancer Care 2010; 19: $648-55$

27. Lyman GH, Lyman CH, Agboola O. Risk models for predicting chemotherapyinduced neutropenia. Oncologist 2005; 10: 427-37.

28. Režonja R, Knez L, Čufer T, Mrhar A. Oral treatment with etoposide in smal cell lung cancer - dilemmas and solutions. Radiol Oncol 2013; 47: 1-13. 